\title{
硝酸蒸解法に依るパルプ製造に關する研究
}

\section{第三十二報 硝酸處理に際しての瓦斯發生（その一）}

下田功

确酸蒸解に際して瓦斯の管生があることは既に報告 乙た通りであるが以下まとめて發生量及び瓦斯の分析

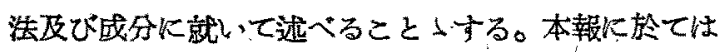
ガスの發生量について迅くる。

ガ ス登生量は硝酸の滋度處理の溫度及び試料的種類 に皮つて異る。以下乙れに就いて述ぺる。

\section{1. 硝酸濃度とガス發生量の關係}

試料としてはブナブターール、リダニン及完全に脫 樹脂したブナ材を用いた。プナ材は50メッシニを通り 80 ッシニに䇅るものを用いた。これのリグニン含有 量は $28.79 \%$ であつた。

こなで問題となるのは發生ガスの容䖽測定裴置です る。著者は色々の㖓置を試作したが結局炏に示す（第 一圖〉が最良でありたので以後報告する筑驗恃全部こ れを用いた。

後速する樣に發生ガス中には No が存在するので装 置の中に初め酸素が要ると誤差を生じる。しかしこれ

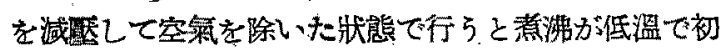
まりりダニンと确酸の作用が起らない。從つて以下の

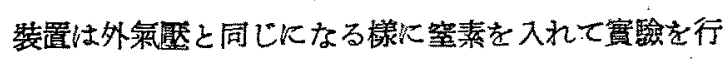
つた。蓝置の說明を次に述べる。

先ず水銀面 $\mathrm{E}$ 上㫒してニックAを用いてR中の空

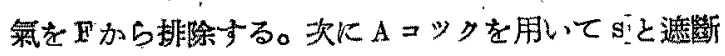

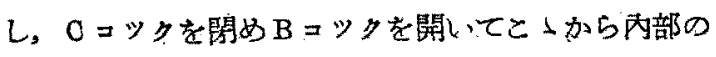
室氣を排除する。大體 $1 \mathrm{~mm}$ 位（水銀柱）になつた、 ならばBを通して純祽の䇪素を入れる。次に又排氧し て窒素を入れ，これを三回繰返えす。かくして裝置內 の室氮は完全に空素と瞽換する。

最後儿等素を入れるときは外㴋壓よりや小隇歷にし て置く。次にニックロを開いて硝酸を所要量だけ注入 ずる。隇毙にして置く程度は注入さる确酸最によつて

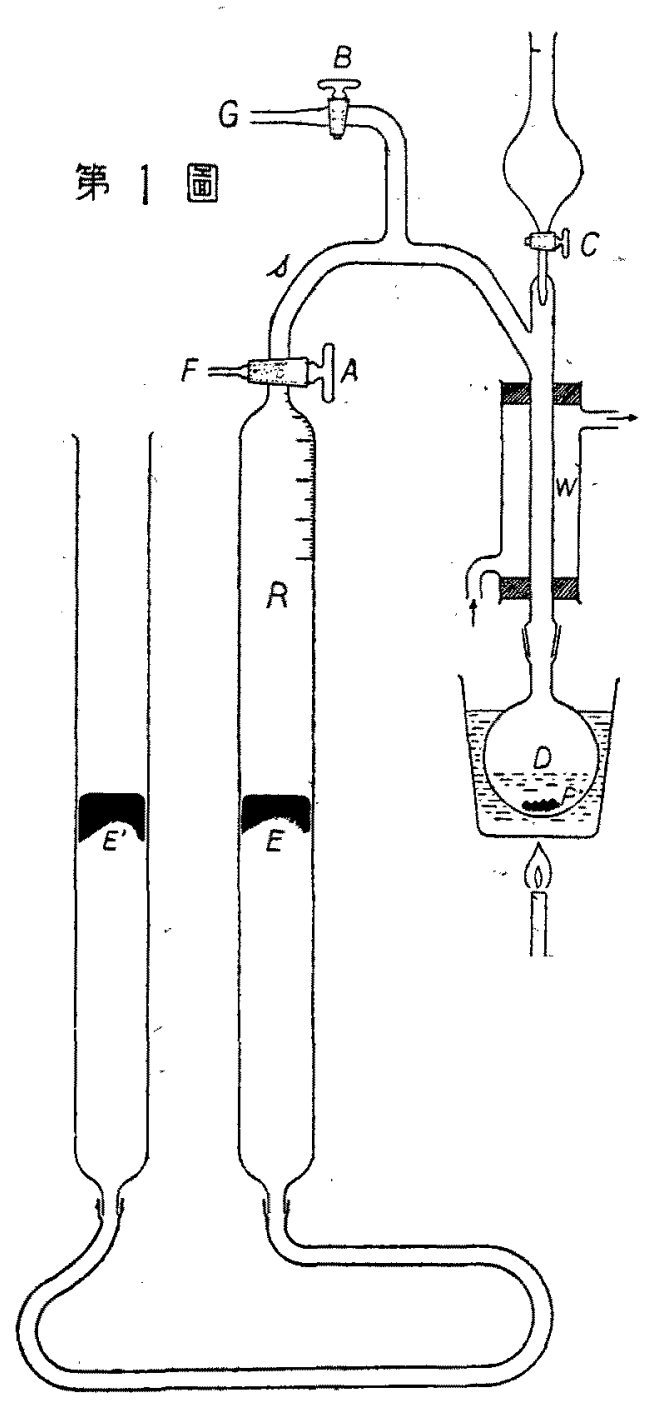

色ネと異る。次にWに冷却水を通じDにて硐酸を煮沸 せしむる。 
漟漂前にコックBから䇪素を入れ內部を外氣壓と同

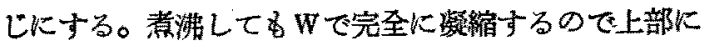
一灣曲部に水がたまることはない。內部の型は當然上 つてくるのでA シックで 面とを同一水本面に保つて一定になる點を讙んで置 $\Sigma_{0}=$

次にD中に試料 $\mathrm{p}$ を入れて前と同じ橉比行つて熱し

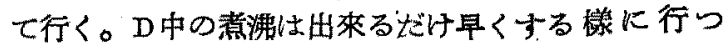
た。

ロツクAでSとRを通じEと $\mathrm{E}^{\prime}$ を一致させて行け ば發生するがス量と時間の關俰を見ることが出來る。

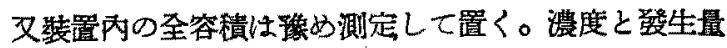

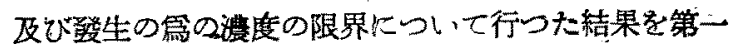
表及び第二國に示す。

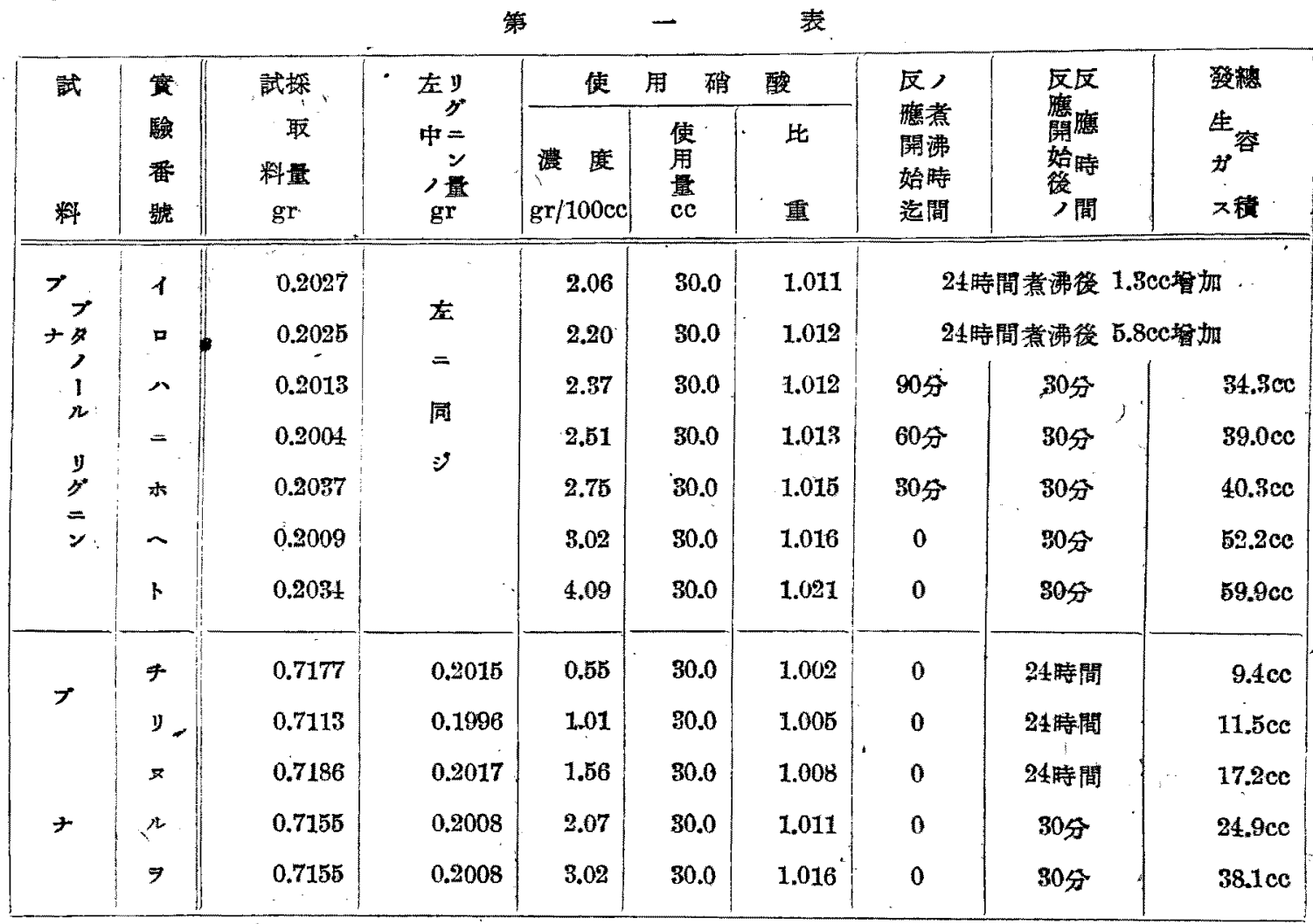

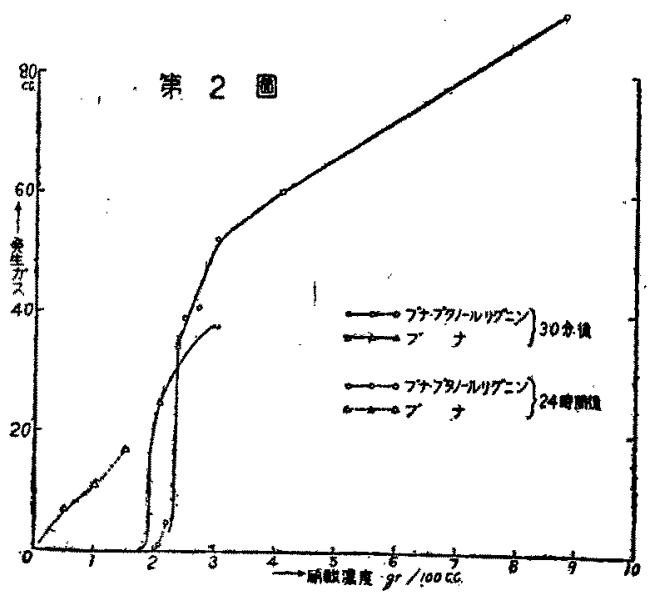

プタノールッグニンは表から嗿らかの様に濃度か;2 \%近くK下つてくると刍に發生が和そくなり一見反噫 は起らない㶹に見られる。然し數時聞位者沸して居る らちに反礁が初亲る。

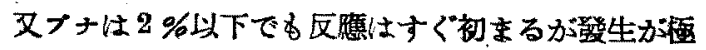
めて除にですり雨方とる2\%近くではつきりした變化 ガ認められる。

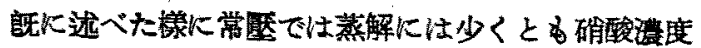
として2\%を要することを認めたがこの點からす理解 される。

$2 \%$ \%下でガスは多少出るがこれは全く異つた焃

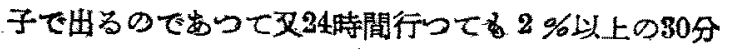
にも及ばねるのである。 
要するに砽酸 $2 \%$ 前後で急にがかか登生し出して蒸 解が初まる。淟度の高い方が篦生ガス量は多い。

\section{2. リターンの種類及び温度の影留}

天然のッグニンと遊離したリダニン，又針葉樹，閿 葉樹， у グ=ン及び禾本科 リ グ=ン等についてのガス 登生に就いて述一゚る。種類としては

蛝费松 (リグニン 32.40\%)

蛝块烃ブタノールリグニン。

$$
\begin{aligned}
& >\quad \forall(\Downarrow タ ゙=ン 28.07 \%) \\
& \text { フォ・ブターールyグ=ン }
\end{aligned}
$$

稻 㩰 $(リ ク ⿻ ン 15.20 \%)$

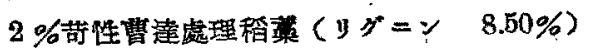

を用い，溫庋は $86.5 \sim 87^{\circ} \mathrm{C}$ と $97.98^{\circ} \mathrm{C}$ の二つを行つ to

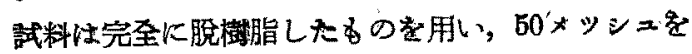

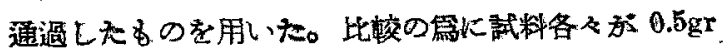
のリグニンを含む檍にした。郎ち次の樣になる。

$$
\begin{aligned}
& \text { 試料 試料使用量 } \\
& \text { ダナブタ゚ンードทダ=ン 0.50gr. } \\
& +\quad \text { 1.78gr. } \\
& \text { 蝦桋松・ブダーール・リグリン 0.50gr. }
\end{aligned}
$$

跟夷、禁

'程 符 $3.29 \mathrm{gr}$.

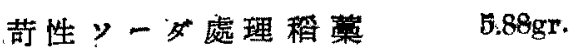

确酸は $5 \%$ \%の 300cc，索用いた。

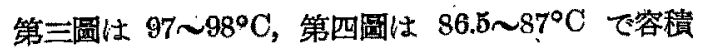
は標準状態に換算してある。

兩圖から見ると先づ溫度高い力が一定特間で發生が

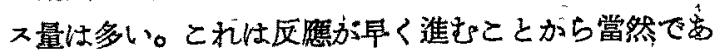

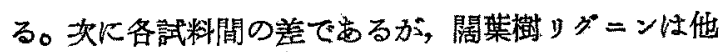
のるのより天然です，遊離物です發生量が多い。これ

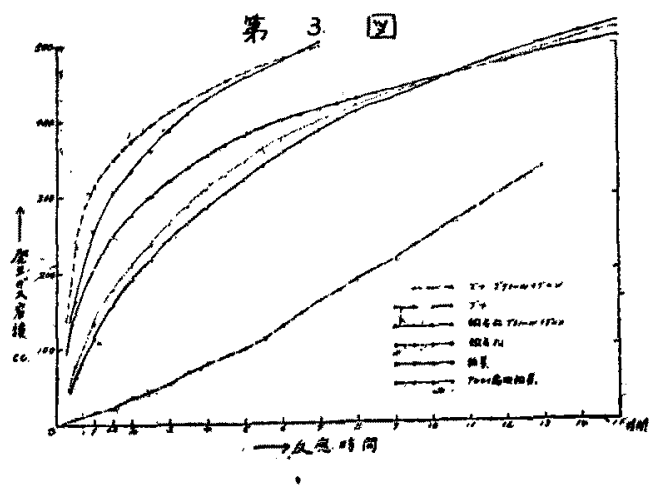

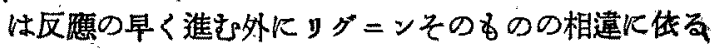
るのである。

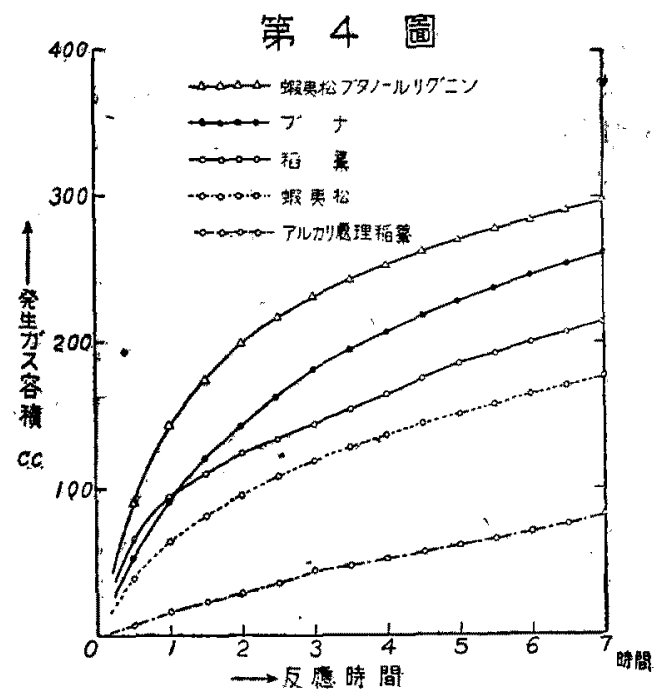

即ち相違の著るしい點はメトォキシル基の含有量て あり头の樣になる。試料のリグニン含有量と試料のメ トォキシル基含有量からリグニンのメトネキシ含有量 を算出した。

$\mathrm{CH}_{3} 0 \%$

$$
\text { プナ・リダニン } 21.20
$$

$$
\text { ブン:プターールリダ }=ン
$$

蝦费松りグニン

16.41

\begin{tabular}{|c|c|c|}
\hline 稻 & 䕱 & $15.20 \%$ \\
\hline 荷性䒼達處 & 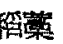 & $8.50 \%$ \\
\hline “夷 & ，棇 & $32.40 \%$ \\
\hline ブ & F & $28.07 \%$ \\
\hline
\end{tabular}

䌟夷松・ブタン゙ール・リダ=ン

15.20

稳萝 yダーン

14.30

$2 \%$ 苛性曹達處理稳菱のりグニン 7.62

考の篇に試料のリダニン含有量と試料の $\mathrm{CH}_{3} \mathrm{O}$ 含有量を示す。(ミクロッアイ七儿法)

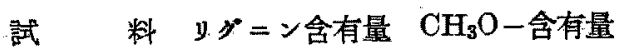

こ机加胃西と $\mathrm{CH}_{3} \mathrm{O}$ - 基の多いリグニン程反鹤

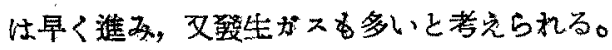

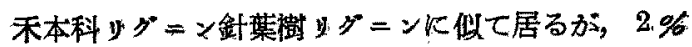

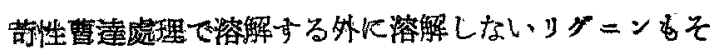
の $\mathrm{CH}_{3} \mathrm{O}$ - 基が分離される樣代考光られるが $2 \%$ の苛性曹達て $\mathrm{CH}_{3} \mathrm{O}$ - 基が分離することも，考え難

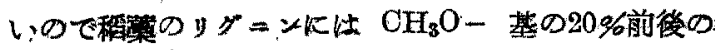
むのと 8 \%前後のるのとの混合と考えるのが管當です 
ろろ。

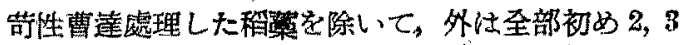
時闃に急激儿發生して，のち怔除々，然し乍ら時間 に比例し增加して終點がない场でする。即ちッグニン が全部分解して了弓迄續くるのと見做される。梸整三 段硐酸蒸解法でガスの發生が函めて少いの出，以上の 實駼からよ之理解される。

\section{3. リダリンと硝酸の割合の影留}

一定量のリダニンK對して用ろる砽酸量を謷えて見 てその影響を見た。その結果初めのうち殆んど同じ でするが長時間になると确酸量の多い方が多くなる。



溥くなつて反應か起らなくなるるのと考える。

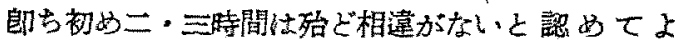
'。

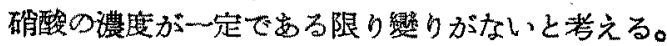

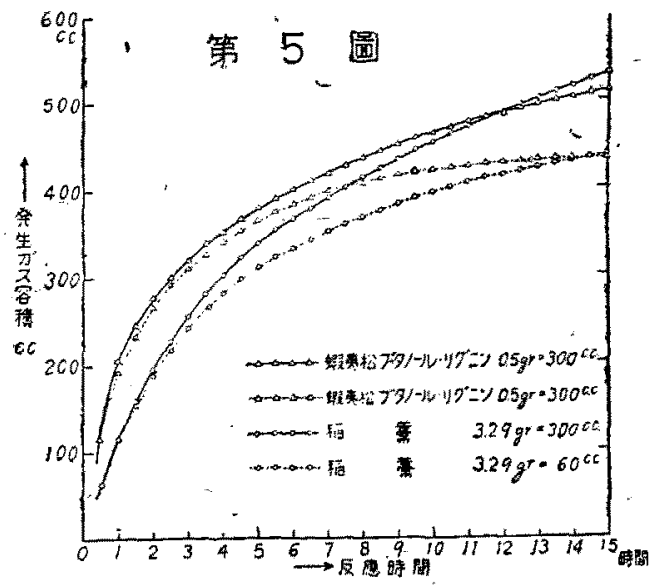

女. 献

1）第28坏 林座化學 第2第3.4㴲 18一-21頁 第29報 林度化學 第 2 第3，4號 22-23頁

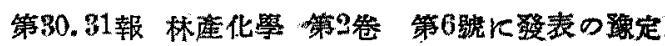

(昭和23年7月19日受理)

硝酸蒸解法に依るパルプ製造に關する研究

第三十三報，硝酸處理に際してのガスの發生（其の二）

下

發生ガスの成分としては文献上には等素，亞酸化窒 素，酸化窒素，一酸化炭素，炭酸ガス，苚酸が認めら れる。

これらのガスの湿合物走分析する雼めにはその吸收 綈及びその順序について考慮を拂らことが必要です

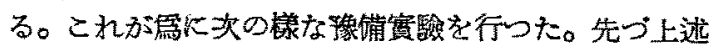

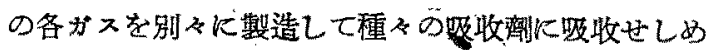
た。そしてこれら混合物の分析順序を決めた。

亞确酸メチルはメチルアルコールに亞喟酸曹達を加 え置きこれに稀硫酸を滴下して登生せしめた。

$\mathrm{N}_{2} \mathrm{O}$ はヒドロキシイルアミンK亚确酸曹達を加えて 製造した。各ガス各各㮔吸收激に吸收せしめた結果は 第一圆に示す樣价なる。



第一圖の結果を考として登生ガスの定性分析に就 いて述べる。 


\section{1. 墢生ガスの定性分析}

\section{(1) $\mathrm{NO}_{2} \odot$ 發 生}

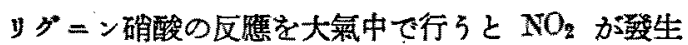
することは黄褐色のガスが出ること又臭からす明らか です。

然しこの $\mathrm{NO}_{2}$ は本來りグニンと硝酸の反䇠から發 生したものでなく登生した NOが空氣中の酸素と化合 して $\mathrm{NO}_{2}$ 一となつたるのである。何となれは前32報の 裝置で，窒菜中で反隹を行らと發生ガスは全く黄色を 帶び妨ことから明らかでする。

但し硝酸のみでを煮沸により亞硝酸を生じこれが及 煮潜によつて

$2 \mathrm{HNO}_{2} \rightarrow \mathrm{HNO}_{3}+2 \mathrm{NO}+\mathrm{H}_{2} \mathrm{O}$ となる。又還元能 力亩る物質があれば

$2 \mathrm{HNO}_{2} \rightarrow \mathrm{H}_{2} \mathrm{O}+2 \mathrm{NO}+\mathrm{O}$ となり, 結局 $\mathrm{NO}$ と が登生して $\mathrm{NO}_{2}$ を生じる可能性もある楾に認められ る。

然しッグニンとの反奬を等素中で行らて發生がスを 苛性加里に吸收せしめてこれをデヷアルが洗で定量乙

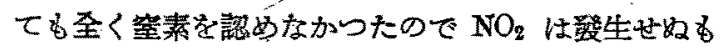
のと認める。

NO 及び $\mathrm{CH}_{3} \mathrm{ONO}$ は二,三分で㤬全く苛性加里に 吸收され妨 $\mathrm{NO}_{2}$ は瞬時にして吸收されるすのです るからもしデヷフルタ゚泆で窒素が出れば $\mathrm{NO}_{2}$ の生成 索認めてよいわけでする。

(口) $\mathrm{CO}_{2}$ 生 成

こ礼は明らかに出來て扂る。苛性加里に吸收される

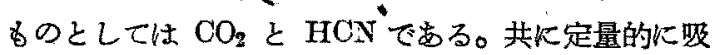
收される。

然しリグニンと确酸の反應に際して反應容器に逆流

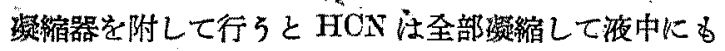
ビるすのでる。

これはがスを菏性加里に吸收せしめてッービッと法 で定量して見ると全く HCNはないことから明らかで ある。從つて苛性加里に吸收されたすのは $\mathrm{CO}_{2}$ とし か考充られぬ。文吸收液に水酸化ベりウムを加一るを

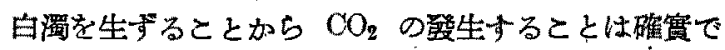
吢る。

\section{() $\mathrm{HCN}$ ○ 發 生}

これは明らか火發生する。反隹器に疑縮器をつけな いで苛性加里中に導入した，これをッーヒッ七洗で定
量すると明らかに HCN の發生が諗められる。た HCN の沸點は他の發生がスに比すると著るてく高い

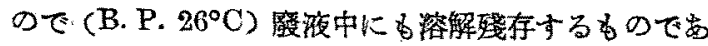
る。

$\Leftrightarrow \mathrm{N}_{2} \otimes$ 發 生

これ㵊後に垡る何物にむ吸收され奴ガスでする。 これは明らかに窒素である。

\section{(杖 $\mathrm{CH}_{3} \mathrm{ONO}$ の發生}

これは交献上に發生の可能性が論ぜられただけで登 生を認めたものはない。ルータル氏，シャールシニミ ット氏等は 00 と誤つて居る。

次のけに於いて諭しる樣に NOは明らかに発生し て居る。又酸素は存在する等がない。何となれば No は存在する限り窒盜 $10-15^{\circ} \mathrm{C}$ で例之酸素が出たと して子 $\mathrm{NO}_{2}$ となり，過剩に存在することは $\mathrm{NO}$ が相

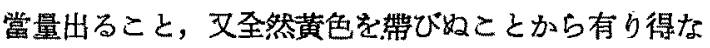
いのでるる。所が發生ガス中には，ビロガロール，又 監化第一銅，監化アンモニヤ，アンニニャ溶㴕の混合 液に吸はれるのが多量にある。

第一圖を見尚と，COはビロガロールに吸方れ如か 5, $\mathrm{Cu}_{2} \mathrm{Cl}_{2}, \mathrm{NH}_{4} \mathrm{Cl}, \mathrm{NH}_{4} \mathrm{OH}$ K吸われて 生を認めることは出來ない。かータラ氏等は，乙の點 で誤つて簡單に CO の登生としたのでする。

借 CO は第一圖から見られる樣に全く登症硫酸には 吸われ2。一方登生ガス中ビロガロール，及び $\mathrm{Cu}_{2} \mathrm{Cl}_{2}$,

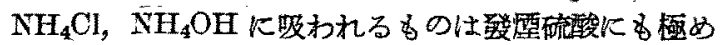
てよく吸收され残りは全くビロガロールにる，又 $\mathrm{Cu}_{2} \mathrm{Cl}_{2}, \mathrm{NH}_{4} \mathrm{Cl}, \mathrm{NH}_{4} \mathrm{OH}$ K与吸收されなくなる。 從つて CO は絕對に發生して居ないと認める。

そこでこのがスはッグ=ンの $\mathrm{OH}_{3} \mathrm{O}$ - 基が分離ず

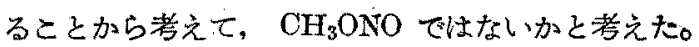
そして $\mathrm{CH}_{3} \mathrm{ONO}$ を別製造して，吸收試䠯をすると 第一圖の樣になつた。

又 $\mathrm{CH}_{3} \mathrm{ONO}$ の溾點は $-12^{\circ} \mathrm{C}$ であるから凝縮器 を附してもガス爿として登生し得るわけでする。故 に $\mathrm{CH}_{3} \mathrm{ONO}$ ではないかと像想して行つた實驗から

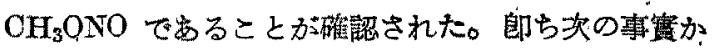
ら明からでする。

(1) $\mathrm{CO}_{2}$ ，NO 学吸收せしめたすとのガスをツフ1 せ几法装置に導入乙て見ると明らか儿 $\mathrm{CH}_{3} \mathrm{O}$ 基の存在を認めた。 


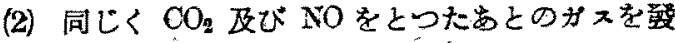
硫酸に吸わせ，この液をルンゲ・ニトロメータ 一下入れ水銀と振湦すると NOが登生する。これ に空氮を入れると直らに黄褐色になる。

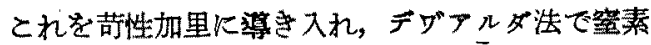
を分析すると窒素の存在を認める。


分解乙，乙の $\mathrm{HNO}_{2}$ か $\mathrm{Hg} \cdot$ と $\mathrm{H}_{2} \mathrm{SO}_{4}$ て $\mathrm{NO}$ 出すのである。

(3) yグニンから分離した $\mathrm{CH}_{3} \mathrm{O}$ - 基の量と酸蒋 液中の $\mathrm{CHO}_{3}$ - 基の量との間には大きな差が吉 る。

(4) $\mathrm{CH}_{3} \mathrm{O}$ - 基は $\mathrm{CH}_{3} \mathrm{OH}$ の形では逆流凝縮器を 附をと出て來ない。

以上迅べたととから亞确酸メチ几が确酸蒸解に際し て瑟生することは礁實である。

(A) NO 0 邆生

この磁生は酸素又は空籍を入れると直ちに黄褐色に なることで明らかでする。

\section{(r) $\mathrm{N}_{2} \mathrm{O}$ の 發}

第一圖を照，最後に殘つたガスを确酸銀溶液に入 れても全く吸はれるものがないから發生して居ないと 考える。

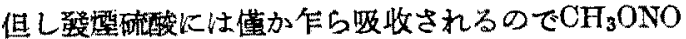
と共にこれに吸收されて了つて居るかす知れぬ。

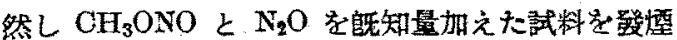
硫酸處理後，硝酸銀溶液處理を行引之既知の $\mathrm{N}_{2} \mathrm{O} の$ 95\%は定量出來たことから，考えると例え發生して居 るとしても極めて微量のるのでする。

\section{2. 墢生カスの定性分析}

以上述ぺて來た所加登生ガ スは $\mathrm{CO}_{2}, \mathrm{NO}, \mathrm{N}_{\mathrm{g}}$ $\mathrm{CH}_{3} \mathrm{ONO}$, 及び $\mathrm{HCN}$ となる。これを头の焃炕操作 分析することなした。

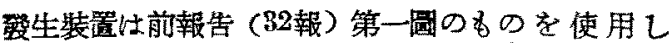
た。

、先つ発生した HCN 碬液化殘存する。從つて採取したガスの中には HCN はない。

第一火苛性加里に㖟收せしめて $\mathrm{CO}_{2}$ を定望する。

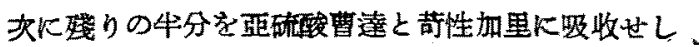

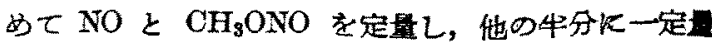
の酸素又は空氣を導入してNO と次の反暃を行わせる。 郎方 $2 \mathrm{NO}+\mathrm{O}_{2} \rightarrow 2 \mathrm{NO}_{2}$

この際の容轱の減少を澌定するか，又忙 $\mathrm{NO}_{2}$ を菏 性加里に吸收せしめでNO を定量する。

或は牛分を筑䃌硫酸に吸收せしめて $\mathrm{CH}_{3} \mathrm{ONO}$ を定 量してるよいが NOが它はり少量吸收されるので正确 を期し䧼い。

又訊料ガスが少量のときは苛性加里に吸收せしめだ 後酸素又は空氮を入れ $\mathrm{NO}$ を $\mathrm{NO}_{2}$ として更に苗性加

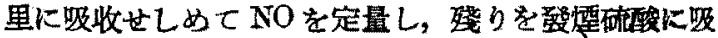
收せしめて $\mathrm{CH}_{3} \mathrm{ONO}$ を定量する。

最後に列つたカスを窒素とした。

次に HCN の定量であるが，洽却近流器を附さない で行えば HCN は發生して探取器の方え出てくる加ら これを苛性加里に吸收せしめて KCN とし硝酸銀で满 定し得る。

この方法はパルブ製造に際してどの位の HCN が登 生するかを自るときにはよいが，正確な結果を期する ときにはよくない。何となれば HCNは全部出ずに一 部は溜液中に垡る。文青酸は沸點が $26^{\circ} \mathrm{C}$ であるから 空温であると装置の所々に凝缩することがある。故に 泠却器を用いてこれを防いで HON U全部液中にのて る漾にした方が發生 HCN を定量するには都合がんい わけである。

これに關して行つた結果を述べる。

\section{リービッヒ法に依る場合}

酸夜を苛性加里で中和して HCN $\mathrm{KCN}$ にする。 これを硝酸銀で滴定する。この锡合に廢液が着色して 居る愗に䅂點を認め難い。而孔廢液中の HCNは僅少 であるので特に認め蜼い。從つてこれは用いられぬ。

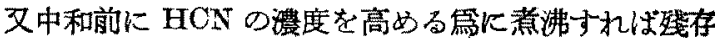
确酸とりグニンの作用が初まり更に HCN は造れ去 る。及冷却器を附寸れば渷度の目的を達しない。何れ にしても意味のない操作となる。 $\mathrm{KCN}$ を $1.0828 \mathrm{gr}$ ，“ $100 \mathrm{cc}$ の水に溶解して，これを $0.1 \mathrm{~N}$ 硝酸銀で，滴定 したときと，これに，硝化りグニン 0.05gr を加へた 場合に既に差䖪出てくる。而も确化りグニンを含んだ 万は必ずしる一定した終點が得られ奴。

硙化 y ク゚ =ン を加えない時

硝化y ゙゚ニン を加之太㭙
$0.1 \mathrm{NAgNO}_{3}$

$0.1 \mathrm{NAgNO}_{3}$ 8.66ce. $8.85-8.95 \mathrm{cc}$ 


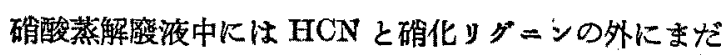
色なの化合物を含んでるのでな牺更終點が明膫に出な い。郎ら，KCN を正確に定量出來ないととは明らか 厄る。

\section{硝䣲銀に依る重量法の場合}

この場合す正確に出娘邲ち确化リグニンが硝酸銀 と沈破を生じる。例えば 0.5gr の福化リダニンを 100

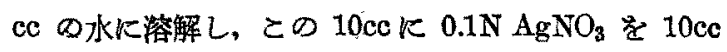
加えると $0.0017 \mathrm{gr} \cdot の$ 沈群を得た。

\section{窟霓ガスで追ひ出す方法}

これも溫度を上げては意味ないので室溫で行つてと れを 8 時間行つたが苛性加里中には KCN 認めない。 即らこれては出て來存。

\section{硫酸銅アンモニヤ法に依る万法}

$\mathrm{CuSO}_{4} \cdot 5 \mathrm{H}_{2} \mathrm{O}$ 6gr. をアンモ=ヤ水に溶解し $250 \mathrm{cc}$
としたもので滴定した。

KON 1.0828gr.を 100cc の水に溶解し，この10cc に硝化リグニン 0.05gr. 加之た場合を加えぬ場合。

又硝化 リグニンのみの場合，につき滴定すると头の 碌になつた。

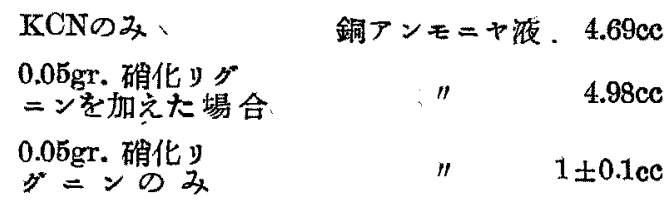

やはり正確を期し難いことが制明した。

終點はリービッヒ法が一番明瞙でする。

以上要なるに青酸ガスの硝酸蒸解に際しての正確な 發生量を定量する方法はないことが㒛められた。

文献

1) P. Klason: Ber. 1929. vol. 62. p. 2523-2526

2) K. Kürschner : Cellulose Chemie. 1940 vol. 18.

(昭和 23 年 7 月 13 日受理)

\section{系、瓜繊維下關する研少一}

\section{第 1 報 理化學的性狀に關する研究}

$\begin{array}{llllllll}\text { 日本女子學 } & \text { 上 } & \text { 田 } & \text { 柳 } & & \\ & \text { 尾家 敏 子 } & \text { 松 } & \text { 原 } & \text { 子 } \\ & \text { 山 崎 芙 } & \text { 美 } & \text { 崎 山 } & \text { 和 子 } \\ & \text { 吉 川 秀 子 } & & & & \end{array}$

\section{1.まへがを}

糸瓜の利用は過去に於て特に衣生活の面では餘りな されなからたのでするが，現在の衣料品の賞乏から， 昨今その利用價値が認められるに至り，そこで私共は その利用について，種 了考慮を衣料品の一部でする帽 子とか，ハンドバッグ，テープル脚，マット，はき物 等に向け，その製作に當つたのであるが，利用に際し 一て先づ禾瓜の性狀を調查し，更に利用についてる科學

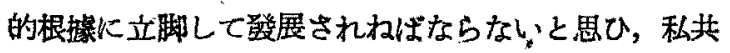

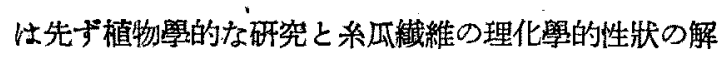
明に當つたのでする。しかし植物學上から見た糸瓜繊

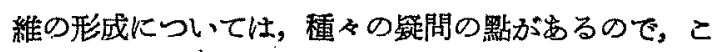
の稿に於ては, その一部でする理化學的性狀の研究結 果比つき遮べる次第である。

\section{2. 米瓜維维の物理的性狀}

系瓜瀻維の物理的性狀に關しては, 過去に於て研究

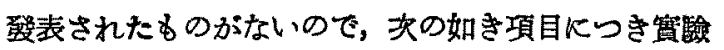

